\title{
Saying That Logging is Either 'Good' or 'Bad' for Fish Doesn't Tell You How to Manage the System¹
}

\author{
by
}

\author{
G.F. Hartman², J.C. Scrivener' ${ }^{2}$, T.E. McMahon ${ }^{2}$
}

\begin{abstract}
A 16-year multi-disciplinary watershed study at Carnation Creek, British Columbia, revealed that different activities in a forest harvest program had different impacts on the physical and biological components of the system. Changes in stream temperature, as a result of logging and a climatic warming trend, and changes in the distribution and volume of woody debris in the channel caused complex sequences of processes to influence salmonid production in both a positive and negative manner. The influence depended on the type of physical change, the fish species and its life history stage, and on the elapsed time after the logging activity. Some direct implications of the research to the problems of managing in the face of complexity are discussed.
\end{abstract}

\section{Résume}

Une étude multi-disciplinaire de 16 ans sur un bassin versant situé à Carnation Creek, Colombie Britannique, a démontré que différentes activités reliées à un programme de récolte forestière ont eu différents impacts sur les constituants physiques et biologiques du système. Les changements dans la température du cours d'eau, suite à l'exploitation forestière et la tendance au réchauffement climatique, ainsi que les changements dans la distribution et le volume des débris de coupe dans le cours d'eau ont provoqué des séquences complexes de processus ayant une influence à la fois positive et négative sur la production de salmonidés. L'influence dépend du type de changement physique, de l'espèce de poisson et de son stade d'évolution, ainsi que du temps écoulé depuis l'exploitation forestière. Quelques implications directes de recherche reliées aux problèmes d'aménagement face à ce problème complexe sont abordées.

\section{Introduction}

This paper reviews briefly results from the Carnation Creek watershed project and considers the application of research results in fisheries-forestry planning. The Carnation Creek Project, started in 1970/71, was planned to meet three main objectives (Narver and Chamberlin 1976):

1. to develop a better understanding of undisturbed coastal rainforest-salmon stream ecosystems;

2. to explain and quantify the impacts of timber production and forest management activities on stream environments and their capacity to produce salmonid fishes; and

3. to provide continual input to developing sound, practicable, integrated-resource management guidelines for the watershed ecosystem.

The first 16 years of the project are complete and approximately 90 articles have been published on it. We are only able to review and discuss the application of a small part of the work in this paper. Objectives of this article are:

1Paper given at Working Group on Wild life and Fish Habitat, Annual Meeting of the Canadian Institute of Forestry, Victoria, B.C. September 1986

2Department of Fisheries and Oceans, Fisheries Research Branch, Pacific Biological Station, Nanaimo, B.C. V9R 5K6.
1. to outline the study;

2. to familiarize forest managers with the main life history characteristics of four species of salmonids that occur in Carnation Creek;

3. to review the processes of change in temperature, debris, channel morphology and gravel conditions in the stream, caused by stream-side logging activities;

4. to comment on some aspects of the processes of change that are important to fishery-forestry planners; and

5. to consider the role of research and its application in resource management.

This paper focusses on ecological processes within the stream system. If 'managed forest' refers to a natural forest system with mixed resource values and multiple users then the quality of management within it will be governed largely by the level of understanding of ecological processes within the system and the degree of application of such understanding. We conclude this paper with some reflections about managing natural systems with multiple resources versus farming economic components of such systems.

\section{Study Area}

The Carnation Creek basin is a $10 \mathrm{~km}^{2}$ drainage located in a western hemlock-western red cedar forest on the south side of Barkley Sound on Vancouver Island, British Columbia 
(Fig. 1). The area has been described in many articles (Scrivener 1975, Narver and Chamberlin 1976, Oswald 1982 , and Hartman 1982). The drainage begins at an elevation of about $700 \mathrm{~m}$ and runs to the sea without intervening lakes. Annual precipitation is $210-480 \mathrm{~cm}$ (Hetherington 1982), $75 \%$ of it falls between October and March, and about $95 \%$ of the precipitation falls as rain. The slopes are steep and stream discharge may rise from $0.3 \mathrm{~m}^{3} / \mathrm{s}$ to $30 \mathrm{~m}^{3} / \mathrm{s}$ in less than 24 hours. Soils on the slopes and flood plain (described by Oswald 1982 and Hetherington 1982) are shallow, but they are subject to erosion if disturbed or exposed. Before the logging, the stream was heavily shaded and seasonal temperatures varied from about $2^{\circ} \mathrm{C}$ in winter to $15^{\circ} \mathrm{C}$ in summer. Stream water was soft and conductivity varied from 18 to $71 \mu \mathrm{mhos} / \mathrm{cm}^{2}$ (Scrivener 1982).

The stream has produced adult returns as great as 4200 chum salmon, 450 coho salmon and 30 steelhead and cutthroat trout, after a fishing harvest. Small numbers of resident cutthroat trout and substantial populations of sculpins also live in the stream.

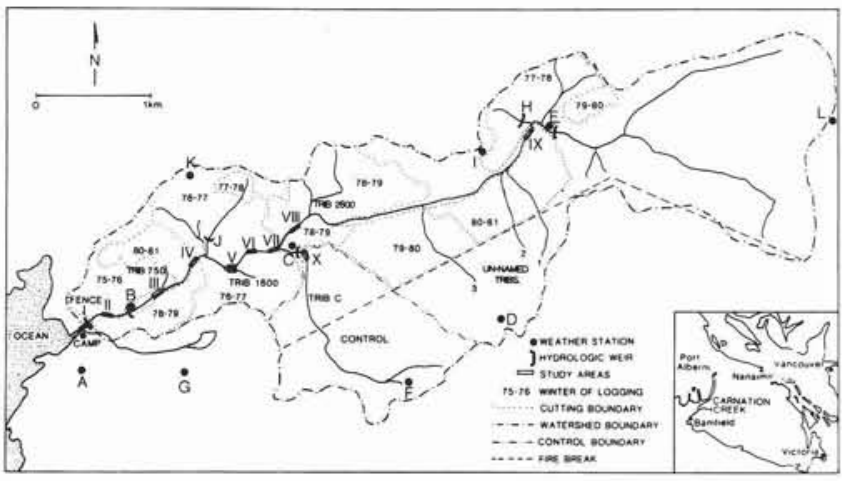

Figure 1. The Carnation Creek drainage and locations of sites where monitoring data were gathered. In the stream, fixed study sites I to X were used for gravel sampling, for mapping channel morphology and large woody debris and for estimating fish populations.

\section{Design of the Study and Methods}

The project was designed to examine the impact of three different stream-side treatments described in Hartman et al. (1987):

1. Leave strip treatment - a strip of trees varying in width from 1 to $70 \mathrm{~m}$ was left along the stream margin.

2. Careful treatment - all but five trees were felled away from the stream; debris was kept from the stream as much as possible; stream-side alder was removed; the cutblock on the south side of the creek was scarified and the one on the north side was burned prior to planting.

3. Intensive treatment - logging occurred simultaneously on both sides of the creek; some trees were felled across the creek and yarded from it; rotten windfalls in or across the creek were broken by falling and yarding; merchantable windfalls were yarded from the creek, stream-side alder were "hacked and squirted" with Tordon $22 \mathrm{~K}$ one year before logging occurred; silvicultural treatment included broadcast burning and replanting of each cutblock.

To evaluate the impacts of these treatments and other activities in the drainage, weather, hydrological conditions, stream temperatures; the location, stability and volume of woody debris in the stream channel; channel morphology, gravel composition, stream insect abundance, numbers of salmonid spawners, numbers of young fish within the steam and numbers of fish going to sea were monitored. This program was begun in 1971 and continued through prelogging (1971-1975), logging (1976-1981) and post-logging (1982-1986) periods. The monitoring sites are indicated on Fig. 1. More details of the program design are given in Hartman et al. (1987).

\section{Life Histories of Salmonids in Carnation Creek}

Four species of salmonids chum salmon, (Oncorhynchus keta), coho salmon (O. kisutch), steelhead trout (Salmo gairdneri) and sea run cutthroat trout (S. clarki) regularly enter Carnation Creek to spawn. Steelhead trout are rainbow trout that spend at least part of their lives in the ocean. Spawners entering from the sea can ascend only $3.1 \mathrm{~km}$ before reaching a natural barrier. Each of the four species of fish depends on the stream in different ways for different lengths of time. The life history patterns are summarized in Table 1, which illustrates that each species exhibits important differences in time of entry to the stream, in distribution within the stream, and in duration of stream residence. Therefore varying responses of the species to logging-induced changes in the stream should be expected.

\section{Logging Activities and Changes in the Stream System}

Logging activities affected drainage basin conditions that determine temperature regimes, hydrological conditions, debris transport, sediment transport, channel configuration, and fish food production. For brevity, we demonstrate only some aspects of the complexity of stream basin processes by discussing sequences of change in temperature regime, in large woody debris, and in stream channel conditions caused by felling and yarding in the stream-side zone. Some of these changes had negative effects on salmonids, some had positive effects and the time frames, over which the changes and their impacts occurred, were different. Generalized effects of temperature and of stream woody debris changes on fish are illustrated in Figures 2 and 3 , respectively. The impacts are both complex and protracted, but they must be understood if informed fisheries/forestry planning is to be achieved.

\section{Temperature Effects}

Logging increased stream temperatures during summer, and both logging and regional climatic trends increased temperatures during winter and early spring (Holtby, in press). Figure 2 summarizes the main types of stream temperature change and the responses of chum and coho salmon populations. The studies and the models upon which Fig. 2 is based were reviewed by Hartman et al. (1987).

The elevation of stream temperature during winter caused both coho and chum salmon fry to emerge from the gravel up to four weeks earlier. Chum fry for the most part migrate directly to the sea after emergence. Evidence from this and other studies (Simenstad et al. prep.; Scrivener 1987) suggests that earlier entry into the ocean increases mortality of young chum salmon. The effects of earlier emergence on coho were positive or negative depending on the stream flows to which they were subsequently subjected. With earlier emergence, there was a greater probability of coho fry encountering higher flows and thus being displaced from the stream in the spring (Hartman et al. 1984). This resulted in greater annual variability in fry numbers. 
Table 1. Notes on time of entry of salmonid spawners, distribution of adults and young fish in the stream and duration of time spent by young fish in the stream (these are only approximate descriptions of behaviour and distribution).

\begin{tabular}{|c|c|c|c|c|}
\hline & \multicolumn{4}{|c|}{ Species } \\
\hline & Chum salmon & Coho salmon & Steelhead trout & Cutthroat trout \\
\hline Spawners enter the stream & Oct. 15 to Nov. 15 & Sept. 15 to Nov. 30 & Jan. 1 to Apr. 30 & Oct. 3 to Apr. 15 \\
\hline Spawning occurs & Oct. 15 to Nov. 15 & Oct. 15 to Dec. 30 & Mar. 15 to May 15 & Mar. 15 to May 15 \\
\hline Distribution of spawners & $\begin{array}{l}\text { Mid-esturay to } 1000 \mathrm{~m} \\
\text { upstream }\end{array}$ & $\begin{array}{l}10 \mathrm{~m} \text { to } 3000 \mathrm{~m} \\
\text { upstream }\end{array}$ & $\begin{array}{l}100 \mathrm{~m} \text { to } 3000 \mathrm{~m} \\
\text { upstream }\end{array}$ & $\begin{array}{l}100 \mathrm{~m} \text { to } 5100 \mathrm{~m} \\
\text { upstream and in small } \\
\text { tributaries }\end{array}$ \\
\hline Migration of fry to sea & $\begin{array}{l}\text { Mar. } 20 \text {-May } 15 \\
\text { (No rearing in stream) }\end{array}$ & $\begin{array}{l}\text { Mar. } 30 \text { to June } 30 \\
\text { (most do not survive) }\end{array}$ & $\begin{array}{l}\text { (fry emerge later) } \\
\text { (few caught at fence) }\end{array}$ & (few caught at fence) \\
\hline First summer in the stream & - & $\begin{array}{l}\text { Reside in stream and } \\
\text { estuary }\end{array}$ & Reside in stream & Reside in stream \\
\hline Movement to flood plain habitat & - & $\begin{array}{l}\text { Sept. } 15 \text {-Dec. } 15 \\
\text { Up to } 1500 \text { young } \\
\text { coho }\end{array}$ & $\begin{array}{l}\text { Oct. } 1 \text { to Nov. } 30 \\
\text { small numbers }\end{array}$ & $\begin{array}{l}\text { Oct. } 1 \text { to Nov. } 30 \\
\text { up to } 100 \text { young trout }\end{array}$ \\
\hline First winter in the stream & - & $\begin{array}{l}\text { Most young reside in } \\
\text { the stream }\end{array}$ & Reside in stream & $\begin{array}{l}\text { Reside in stream and } \\
\text { small tributaries }\end{array}$ \\
\hline Second summer in the stream & - & $\begin{array}{l}60 \text { to } 90 \% \text { of the coho } \\
\text { go to sea as smolts }\end{array}$ & Reside in stream & Reside in stream \\
\hline Second winter in the stream & - & Reside in main stream & Reside in stream & Reside in stream \\
\hline Third summer in the stream & - & $\begin{array}{l}\text { Remaining } 10 \text { to } 40 \% \\
\text { go to sea as smolts }\end{array}$ & Some to sea as smolts & Some to sea as smolts \\
\hline Third winter in the stream & - & - & Reside in stream & Reside in stream \\
\hline Fourth summer in the stream & - & - & $\begin{array}{l}\text { Remainder to sea as } \\
\text { smolts }\end{array}$ & Some to sea as smolts \\
\hline
\end{tabular}

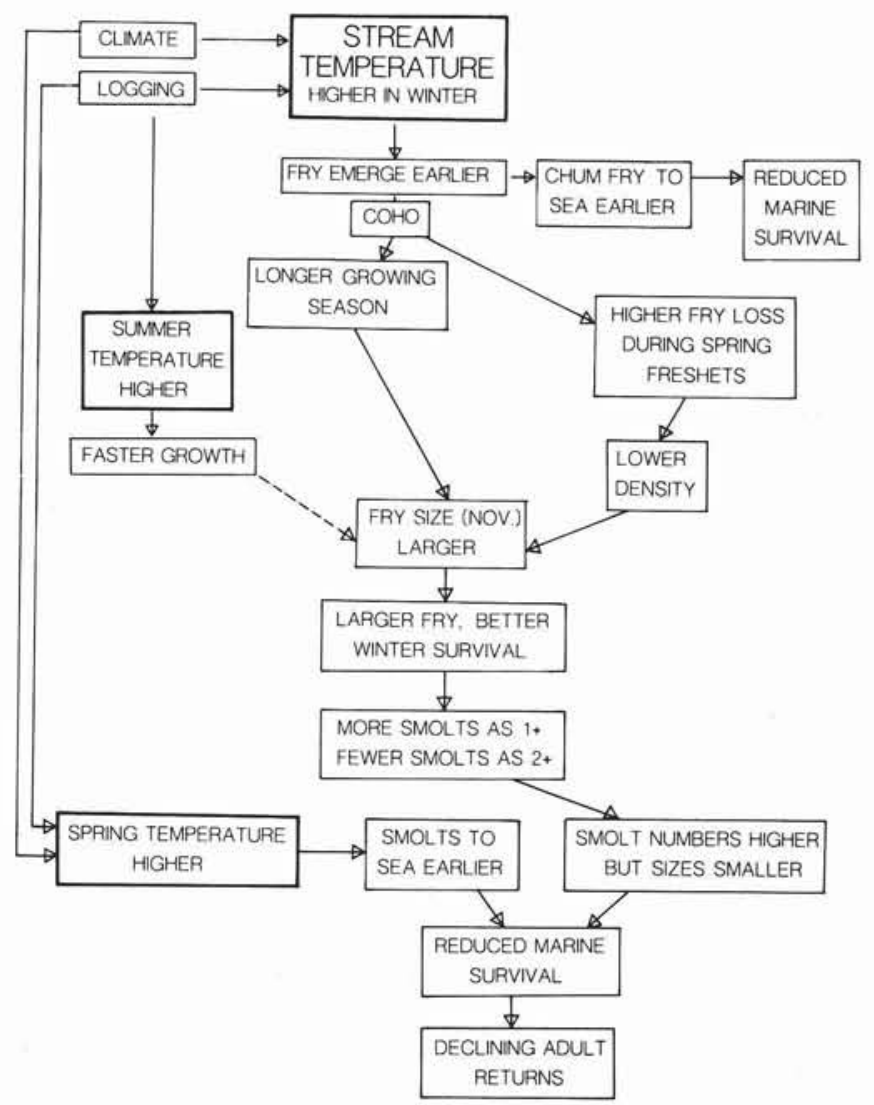

Figure 2. A schematic diagram outlining causes and seasons of temperature change and some responses of coho and chum salmon to such changes.
Most of the displaced fry went to sea and they did not contribute to adult returns, but some of them resided in the estuary during the summer. With earlier emergence, coho that remained in the stream had a longer summer growing season and thus were larger in the late autumn than were fry of the pre-logging period (Fig. 2). More of these larger fish survived the winter and they were larger in the spring than were fish during pre-logging years. Consequently, a larger fraction of the coho migrated to the sea as one-year smolts. Smolts are salmonids that are physically and physiologically changing prior to moving from freshwater to the marine environment During pre-logging years, $50-70 \%$ of the coho smolts were one-year-old; however, during and after logging $90-98 \%$ of them entered the sea as one-year-olds (Fig. 2). Therefore, during the first few years after logging, increased growth led to higher overwinter survival and increased numbers of smolts which were predominantly one-year-old fish (Fig. 2). Thus, numbers of smolts increased $71 \%$ between 1978 and 1984 (Hartman et al. 1987).

From these year classes, adult returns actually declined (1980-1985) for several reasons. First, stream temperature conditions that caused fry to emerge earlier also caused smolts to go to sea earlier during the following spring (Holtby, in press). Second, average size of smolts, was smaller because large two-year-olds were no longer being produced. Based on studies of smolt timing and size at release, greater marine mortalities could be expected (Bilton et al. 1982). Therefore, only a $19 \%$ increase in adult returns was anticipated from the $71 \%$ increase in smolt numbers (Holtby, in press). However, even the $19 \%$ increase in adult returns failed to occur during some years because of differences observed in the marine environment, not because of increased fishing (Holtby, in press). 
Temperature increases during the summer were caused by logging and not by a combination of logging and climatic effects (Holtby, in press). These temperature increases were only a minor contributing factor to the increase in size of young coho salmon (Fig. 2, Holtby, in press; Hartman et al. 1984). On the other hand, the increase in stream temperature during summer had a positive effect on the size of trout (unpublished data).

In conclusion, our results show that temperature increases in the stream produced some positive (increased size of fry and increased smolt numbers) and some negative effects (greater marine mortality) on salmonid production. The nature of the effect depended on the species and the life stage of the fish. Temperature increases during winter, spring and summer had differing effects on salmonids. Changes that occurred during the incubation period affected coho life history patterns more than a year later.

\section{Debris Effects}

Stream-side logging and some limited yarding in the stream caused a loss of large woody debris and initially an increase of small wood debris in the channel. This affected fish cover, stream channel stability, gravel stability, and gravel quality (Fig. 3). The small debris was less stable and it was moved during freshets within a few years. Virtually all of the changes that occurred as a result of the reduction in volume and stability of woody debris had negative effects on fish production (Fig. 3).

Reductions in the volume and stability of woody debris occurred about two years after logging in the intensive and careful treatment sections. The increased bank erosion that also occurred in these sections appeared to be caused by two sets of events. First, the buffering of stream energy was reduced when large stable woody debris was lost from the channel. Second, cohesion of the stream bank was reduced when tree roots began decaying. Bank erosion subsequently led to a major decline in the quality of gravel in Carnation Creek by increasing the amount of sand in the streambed. The increase of sands in the gravel and the increase in scour led to reduced egg-to-fry survival and reduced sizes of emerging fry for both chum and coho salmon (Scrivener and Brownlee ms.).

The negative impacts of poorer gravel quality, lower fry numbers, and loss of large stable debris (cover) in the main creek were offset in part by better growth among young coho and cutthroat trout. Large debris provided cover and deep stable pools for over-winter habitat. During many years, coho compensated for reduced numbers by growing faster at the lower densities (Fig. 3). Such larger fish had higher overwinter survival. In addition, young coho salmon and cutthroat trout used flood-plain tributaries and ponds (off-channel habitat) during winter reducing the severity of the impact of the loss of woody debris in the mainstream (Fig. 3). Thus, as many as 1000 smolts could be produced annually from off-channel sites regardless of the change in winter habitat in the main channel (Brown 1985). As a result of these circumstances numbers of coho smolts declined after 1980 and were within the range of pre-logging numbers during 1984 to 1986 (Hartman et al. 1987).

Chum salmon were less dependent on protective cover from stable woody debris than young coho salmon and trout, because they left the stream shortly after emerging from the streambed. However, because of reduced egg-to-fry survival after logging, (due to poorer gravel quality), they entered the

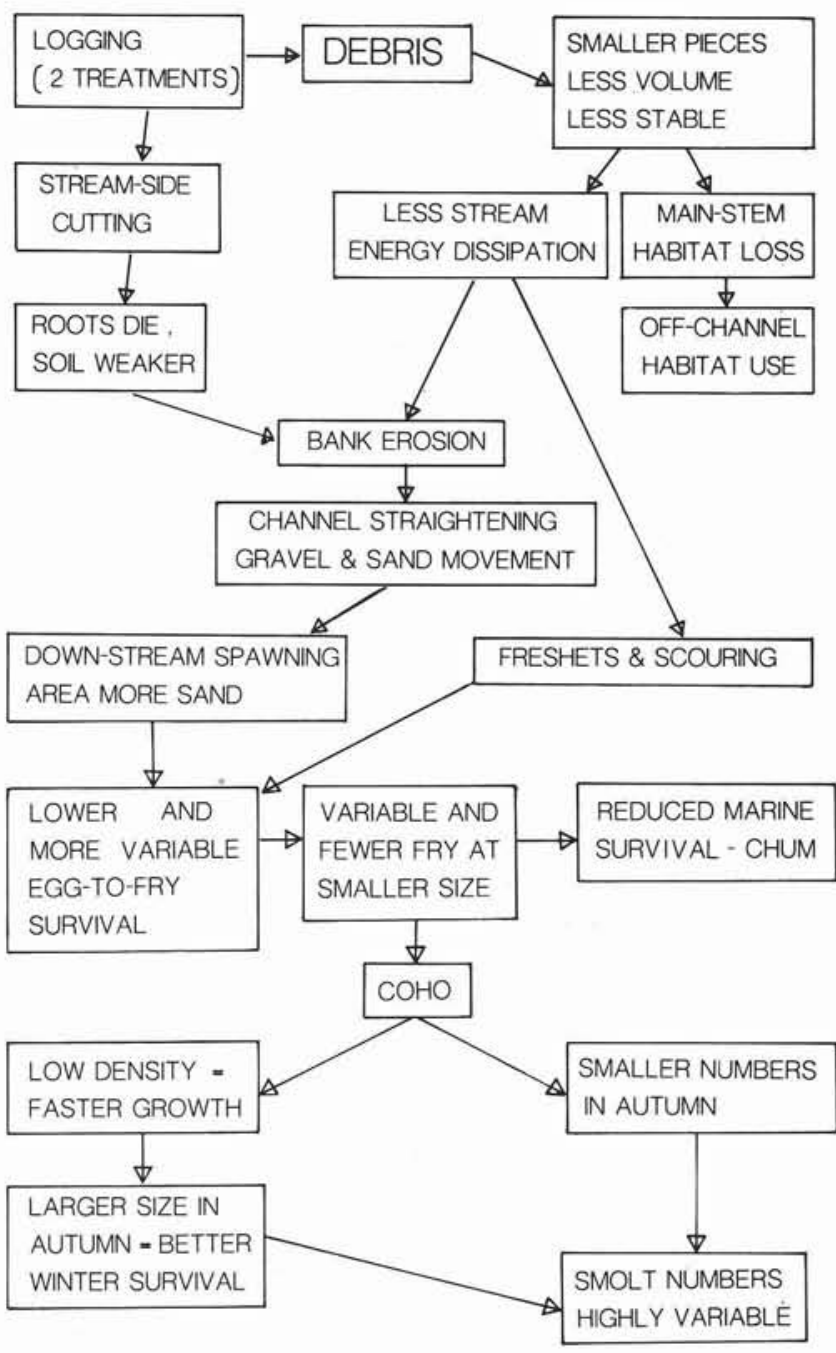

Figure 3. A schematic diagram outlining the causes of change of debris and channel conditions and impacts of these changes on salmon and trout.

ocean in smaller numbers and at smaller sizes. Both of these changes caused lower marine survival and reduced adult returns (Scrivener 1987). Therefore, the reduction of debris volume and stability led to a sequence of changes in the stream with many negative effects on fish survival. It is important to note, however, that different salmonid species were not affected in the same way by the processes of change associated with debris destabilization and loss.

\section{Application of Research Results}

To this point, we have considered only the sequences of change caused by temperature increases and debris loss. The more complete spectrum of management activities that occurs during forest harvest has additional impacts on the stream environment. Figure 4 indicates the changes that occurred in the Carnation Creek system, and it indicates which forestry activities caused the changes. It shows that in the Carnation Creek system most of the changes that occurred were associated with streamside logging activities. It also shows, however, that in other drainages with different physical features, important impacts may be caused by upslope activities. Figure 4 shows that one activity may cause a particular change, another activity, later, may reverse the change (see temperature of the stream, streamside cutting 


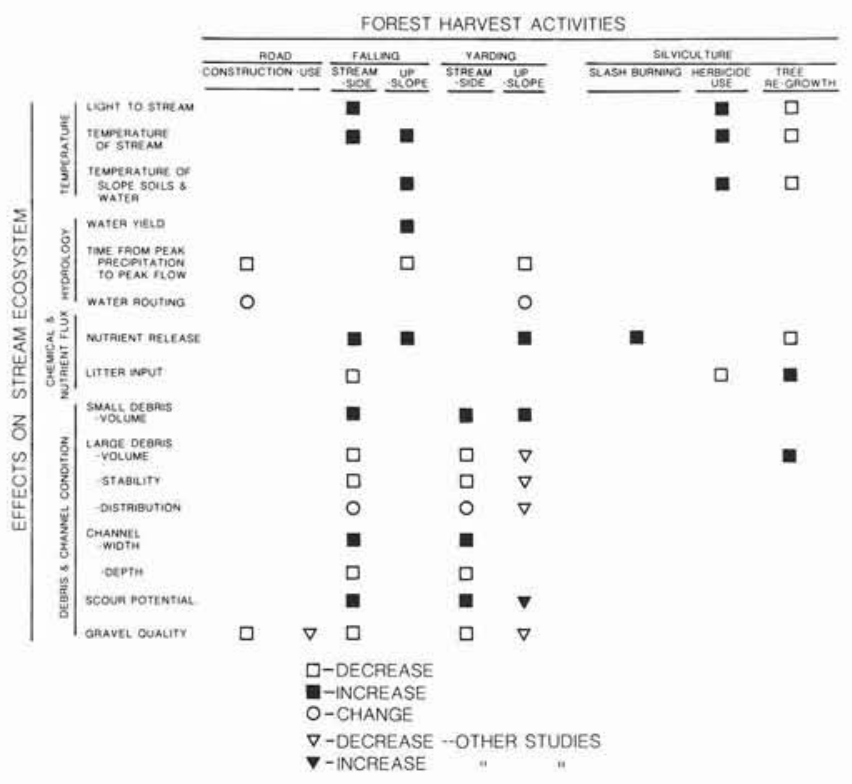

Figure 4. A matrix of logging activities and impacts on physical conditions in Carnation Creek. Some effects of logging activities from studies in the Queen Charlotte Islands and the Olympic Peninsula, indicated by triangles, are included to illustrate differences between geographical areas.

and re-forestation). Although Figure 4 does not illustrate effects on fish it does show changes that, fisheries managers may know, will have positive effects on one species and negative effects on another. If resource managers understand these ideas, and if they have good site specific information, the matrix in Figure 4 represents a format for summarizing expected changes in a watershed as a result of forest harvesting

Expected changes may be greater or smaller with different logging plans or watershed orientations. However when a matrix of likely physical changes is laid out, managers may then begin to predict the effects of such changes on the stream ecosystem as a whole. They may also begin to plan to ameliorate negative effects and retain positive effects.

\section{Conclusions}

It is beyond the scope of this paper to review all of the specific applications of the Carnation Creek work. The project has, however, confirmed some of our perceptions and it has provided new insights. Results from the study indicate that:

1. Most of the forest harvesting impacts on fish habitat at Carnation Creek were related to activities in the streamside zone. In drainages with higher, steeper or less stable slopes, and with deeper soils, up-slope activities could also produce measurable effects.

2. Different forest harvesting activities affect different elements within a drainage system and their effects are not necessarily completely positive or negative.

3. Whether logging impacts enhance or depress salmonid populations depends on the species and life stages of the fish.

4. Impact effects also occur over different time scales. Large woody debris began declining after two years, but it will not be replaced naturally for decades along the clear-cut stream. Temperature increases were observed immediately, but they will begin to decline after one decade as the canopy again closes over the stream.
5. Impacts from an activity depend on watershed location. During summer, temperature increases caused by clearcutting may enhance fish growth in cold streams on the west coast of Vancouver Island, but they may depress growth in warmer streams on the east coast of Vancouver Island or in the interior of the continent.

6. Logging caused temperature changes during winter and early spring that had important and previously unknown effects on salmonid populations.

7. Large debris had a critical function in determining the stability and diversity of the stream channel, and the quality and stability of gravel used by salmonid spawners.

8. Small floodplain tributaries and ponds, some of which can be dry during summer, provide critical habitat for salmonids during winter, e.g. as many as $23 \%$ of the coho produced in Carnation Creek overwintered in floodplain habitat (Brown 1985).

Long term, multi-disciplinary studies like those of the Carnation Creek Project reveal complex ecological processes that occur in stream ecosystems. These processes must be understood to plan effectively for multiple use of resources. Managers may wish to receive simplified and short research explanations; however, natural systems have not evolved over thousands of years with the objective of being easy for man to manage. In fact, the success of salmonid species is probably the result of their opportunistic nature in a very dynamic environment. Proper management of forest systems, which contain valuable species of animals with diverse life histories, demands a sophisticated understanding of physical and ecological processes within the system. It also demands that such understanding be applied. Our management of multiple resource systems is often flawed by a combination of excessive demand and ignorance of ecological processes. It is likely that the conflicts that arise from such excessive demand and ecological naivete are major elements that drive man from the complex management of natural systems to the single product management of the "farm'. If the "man-made" or "managed forest" of the future is to be a single product system such transition to the farming process is not a failure. If, however, as a common social goal, the forest is to remain a complex system with diverse species of plants and animals, with a mix of users, then such transition to the farming process represents either institutional failure by society or intellectual failure by managers, or both. This observation applies equally to fisheries, wildlife, and forestry managers.

\section{Acknowledgements}

The Carnation Creek project has lasted for 16 years during which many people and agencies have either worked in or supported the project. We are grateful to all of them and to MacMillan and Bloedel Limited for their help. Over the years the fisheries field work was carried out by B. Andersen, R. Leahy, T. Brown and P. Neaves in particular. We thank them for their efforts, made without complaint, under all conditions.

\section{References}

Brown, T.G. 1985. The role of abandoned stream channels as overwintering habitat for juvenile salmonids. M.S. Thesis, Dept. of Forestry, U.B.C., Vancouver. 134 p.

Hartman, G.F. 1981. The study area: an initial description, p. 15. In G. Hartman (ed.). Proceedings of the Carnation Creek Workshop, A 10 -year review. Pacific Biological Station, Nanaimo, B.C. $404 \mathrm{p}$.

Hartman, G.F., L.B. Holtby, and J.C. Scrivener. 1984. Some effects of natural and logging-related winter stream temperature changes on the early life history of coho salmon in Carnation 
Creek, p. 141-149. In Meehan, W.R., T.R. Merrell, and T.A Hanley (ed.), Proceeding of a Symposium: Fish and Wildlife Relationships in Old-growth Forests. 425 p. Available from J.W. Reintjes, Rt. 4, Box 85, Morehead City, N.C. 28557

Hartman, G.F., J.C. Scrivener, L.B. Holtby and L. Powell. 1987. Some effects of different stream-side treatments on physical conditions and fish population processes in Carnation Creek, a coastal rain-forest stream in British Columbia, p. 330-372. In E. Salo and T. Cundy (ed.), Proceedings of a symposium Streamside Management-Forestry and Fishery Interaction. Univ. Washington. 471 p. College of Forest Resources, AR-10, Univ. Wash., Seattle.

Hetherington, E.D. 1982. A first look at logging effects on the hydrologic regime of Carnation Creek Experimental Watershed, p. 45-63. In G. Hartman (ed.), Proceedings of the Carnation Creek Workshop. A 10-year review. Pacific Biological Station, Nanaimo, B.C. 404 p.

Holtby, L.B. (In Press.) Some effects of logging-related stream temperature changes on a stock of coho salmon (Oncorhynchus kisutch). MS submitted to Can. J. Fish. Aquat. Sci.

Narver, D.W. and T.W. Chamberlin. 1976. Carnation Creek - An experiment towards integrated resource management. Can. Fish. Mar. Serv. Circular 104. 20 p.
Oswald, E.T. 1982. Preharvest vegetation and soils of Carnation Creek Watershed, p. 17-35. In G. Hartman (Ed.), Proceedings of the Carnation Creek Workshop. A 10-year review. Pacific Biological Station, Nanaimo, B.C. 404 p.

Scrivener, J.C. 1975. Water, water chemistry and hydrochemical balance of dissolved ions in Carnation Creek watershed, Vancouver Island, July 1971-May 1974. Can. Fish. Mar. Serv. Tech. Rep. 564. $141 \mathrm{p}$.

Scrivener, J.C. 1982. Logging impacts on the concentration patterns of dissolved ions in Carnation Creek, British Columbia, $p$. 64-80. In G. Hartman (ed.), Proceedings of the Carnation Creek Workshop, A 10-year review. Pacific Biological Station, Nanaimo, B.C. 404 p.

Scrivener, J.C. 1987. A summary of population responses of chum salmon to logging in Carnation Creek. British Columbia between 1970 and 1986. MS presented at the Carnation Creek Workshop, January 13-15, 1987, Nanaimo, B.C. 24 p.

Scrivener, J.C. and M.J. Brownlee. Gravel quality, forest harvesting and incubation survival of chum and coho salmon in Carnation Creek, British Columbia. MS. for submission to Can. J. Fish. Aquat. Sci.

Simenstad, C.A., R.C. Wissman, and J.R. Cordell. Demography of juvenile chum salmon (Oncorhynchus keta) outmigration in Hood Canal, Washington: co-evolution limitations on carrying capacity. Manuscript in preparation, Univ. Washington, Seattle. 